Ethos (Jurnal Penelitian dan Pengabdian Masyarakat): 191-198

\title{
Pengembangan Model Services Quality untuk Peningkatan Kualitas LAYANAN AKADEMIK INTERNAL di PERgurUan TINGgi
}

\author{
${ }^{1}$ Nugraha, ${ }^{2}$ Aswardi Nasution, ${ }^{3}$ Reni Amaranti
}

\author{
1,2,3 Jurusan Teknik Industri, Universitas Islam Bandung, Jl. Tamansari No. 1 Bandung 40116 \\ e-mail: ${ }^{1}$ Nugraha692004@yahoo.com, ${ }^{2}$ Aswardinasution@yahoo.com, ${ }^{3}$ Reniamaranti2709@yahoo.com
}

\begin{abstract}
Abstrak. Penelitian ini mengkaji kualitas layanan akademik internal pada Perguruan Tinggi, Penelitian ini menggabungkan, pendekatan teori/konsep,penelitian dan pengukuran kualitas layanan akademik perguruan tinggi, metode analisis data dalam penelitian ini adalah menggunakan Structural Equation Modeling (SEM), Berdasarkan perhitungan Indeks Goodness of fit bahwa semua kriteria pengujian menunjukkan hasil yang baik. Pengujian model yang dilakukan menghasilkan konfirmasi yang baik atas dimensi - dimensi faktor dan hubungan kausalitas antar faktor. Dengan demikian model tersebut dapat diterima. Berdasarkan hasil penelitian faktor - faktor pembentukan kualitas layanan akademik adalah tampilan elemen fisik, empati, daya tanggap, kehandalan, jaminan serta pengelolaan. Sedangkan model yang diusulkan kualitas layanan akademik perguruan Tinggi adalah lingkungan fisik, kehandalan dalam layanan, daya tanggap, jaminan, empati, suasana akademik, sistem informasi serta pengelolaan.
\end{abstract}

Kata kunci: kualitas layanan, pengembangan model, service quality

\section{Pendahuluan}

Salah satu kondisi yang dihadapi dunia pendidikan tinggi Indonesia saat ini merupakan masalah persaingan yang bersifat lokal,regional dan global. Perguruan Tinggi di Indonesia, baik yang berstatus negeri atau swasta tidak hanya bersaing dengan Perguruan Tinggi lokal tetapi juga berbagai institusi yang merupakan jaringan dari Perguruan Tinggi di tingkat internasional.

Dari pangkalan data pendidikan tinggi (PDPT) direktorat jenderal pendidikan tinggi Kementerian Pendidikan Nasional menyebutkan jumlah dan jenis Perguruan Tinggi Negeri dan Swasta di Indonesia, seperti terlihat pada tabel 1.

Tabel 1. Jumlah dan Jenis Perguruan Tinggi Negeri dan Swasta di Indonesia

\begin{tabular}{|c|c|c|c|c|c|c|}
\hline $\mathrm{PT}_{\mathrm{PT}}$ Jenis PT & Akademik & Politeknik & $\begin{array}{l}\text { Sekolah } \\
\text { Tinggi }\end{array}$ & Institut & Universitas & $\begin{array}{l}\text { Akademik } \\
\text { Komunitas }\end{array}$ \\
\hline Negeri & 87 & 96 & 77 & 29 & 72 & 3 \\
\hline Swasta & 1007 & 132 & 2235 & 94 & 441 & 0 \\
\hline Jumlah & 1094 & 228 & 2312 & 123 & 513 & 3 \\
\hline
\end{tabular}

Sumber : pdpt dirjen dikti kemdiknas (http://pdpt.dikti.go.id/26 Juni 2015)

Service quality dalam bentuk berbagai layanan yang diberikan institusi khususnya kepada pelanggan/klien eksternal dan internal adalah penting, satu - satunya indikator prestasi yang penting dalam layanan pendidikan adalah kepuasan pelanggan (Sallis, 2011 ; 66) dalam mewujudkan kualitas dalam bidang akademik sebagai output nyata. 
Untuk bisa bersaing dengan perguruan tinggi lain diantaranya adalah meningkatkan kualitas layanan dalam bidang akademik, layanan yang diberikan perguruan tinggi tidak cukup hanya diberikan kepada mahasiswa saja sebagai pelanggan eksternal utama tetapi dosen dan karyawan sebagai pelanggan internal juga harus diberikan layanan oleh perguruan tinggi dari mulai pengembangan SDM melalui studi lanjut,seminar, pelatihan, sarana dan prasarana kegiatan proses belajar mengajar, kesejahteraan, keamanan, layanan administrasi, perhatian dari pimpinan.

Berdasarkan kondisi di atas, peneliti tertarik untuk mengkaji kualitas layanan yang diberikan manajemen internal perguruan tinggi terhadap dosen dan karyawan dengan judul penelitian adalah "Pengembangan Model Services Quality untuk Peningkatan Kualitas Layanan Akademik Internal di Perguruan Tinggi”. Subjek penelitian adalah dosen dan karyawan dan Universitas Negeri dan Swasta di Kota Bandung.

Berdasarkan uraian diatas, maka masalah - masalah penelitian yang dikaji adalah sebagai berikut : (1) Bagaimana faktor - faktor pembentuk dimensi/variabel kualitas layanan akademik internal di Perguruan Tinggi.(2) Bagaimana pengembangan model kualitas layanan akademik internal pada Perguruan Tinggi

Adapun tujuan yang ingin dicapai dalam penelitian ini adalah sebagai berikut : (1) Untuk mengetahui faktor - faktor pembentuk dimensi/variabel kualitas layanan akademik internal di Perguruan Tinggi di Kota Bandung. (2) Untuk mengembangan dan mendapatkan model awal kualitas layanan akademik internal pada Perguruan Tinggi. Dengan urgensi penelitian sebagai berikut : (1) Bagi Ilmu Pengetahuan, Dari Penelitian ini diharapkan dapat memberikan kontribusi bagi pengembangan Ilmu Pengetahuan, penelitian ini diharapkan dapat mengkaji beberapa konsep dan teori yang sudah ada dan berusaha menemukan atau mengembangkan konsep - konsep dalam lingkup Manajemen kualitas layanan khususnya bidang akademik yaitu perguruan tinggi. Penelitian ini juga diharapkan dapat dijadikan sebagai salah satu tolak ukur untuk strategi peningkatan kualitas layanan pada perguruan tinggi baik negeri dan swasta. (2) Bagi Praktisi Sebagai alat bantu pengawasan dan evaluasi serta masukan terhadap kinerja kualitas layanan Perguruan Tinggi sehingga perkembangan mutu Perguruan Tinggi terpelihara berkesinambungan dan dapat bersaing secara sehat dengan Perguruan Tinggi lainnya.

Faktor/Standar/Model yang digunakan dalam pengembangan ini adalah Model kualitas layanan yang digunakan adalah model Service quality, Akreditasi Institusi Perguruan Tinggi (AIPT) - Badan Akreditasi Nasional Perguruan Tinggi (BAN-PT), serta penilaian kinerja pelayanan publik menteri Pendayagunaan Aparatur Negara (Menpan) nomor : KEP/25/M.PAN/2/2004 Tentang Indeks Kepuasan Masyarakat

\section{Kajian Pustaka}

Kualitas layanan menurut Kotler (2009 : 399) harus dimulai dari kebutuhan pelanggan dan berakhir dengan kepuasan pelanggan serta persepsi positip terhadap kualitas layanan.

Kualitas Layanan Akademik Perguruan Tinggi adalah sebagai ukuran seberapa bagus atas keunggulan atau keistimewaan tingkat layanan secara menyeluruh yang diberikan oleh perguruan tinggi sehingga dapat memenuhi kebutuhan/keinginan pelanggan (eksternal utama dan internal), serta ketepatan untuk mengimbangi atau sesuai dengan harapan pelanggan. 
Zeithaml, Berry, dan Parasuraman (2008) mengidentifikasi lima dimensi pokok yang berkaitan dengan kualitas layanan, kelima dimensi kualitas jasa model ServQual. Kelimanya disajikan secara berurutan berdasarkan nilai pentingnya menurut pelanggan,yaitu meliputi : (1) Keandalan (Reliability), dimensi ini mencakup kemampuan perusahaan/institusi untuk memberikan layanan yang akurat sejak pertama kali tanpa membuat kesalahan apapun dan menyampaikan jasanya sesuai dengan waktu yang telah disepakati. (2) Daya tanggap (Responsiveness), dimensi ini mencakup kesediaan dan kemampuan para karyawan untuk membantu para pelanggan dan merespon permintaan mereka, serta menginformasikan kapan jasa akan diberikan dan kemudian memberikan jasa secara cepat. (3) Jaminan (Assurance), dimensi ini mencakup perilaku karyawan yang mampu menumbuhkan kepercayaan pelanggan terhadap perusahaan/institusi dan perusahaan/institusi bisa menciptakan rasa aman bagi pelanggannya. Jaminan ini berarti bahwa para karyawan selalu bersikap sopan dan menguasai pengetahuan dan keterampilan yang dibutuhkan untuk menangani setiap pertanyaan atau masalah pelanggan. (4) Empati (Empathy), berarti perusahaan/institusi memahami masalah para pelanggannya dan kesediaan/bertindak demi kepentingan pelanggan, serta memberikan perhatian personal kepada para pelanggan dan memiliki jam operasi yang nyaman. Seperti kemudahan untuk menghubungi perusahaan/institusi, kemampuan karyawan untuk berkomunikasi dengan pelanggan, dan usaha perusahaan untuk memahami keinginan dan kebutuhan pelanggannya. (5) Tampilan elemen fisik/ Berwujud (Tangible), dimensi ini mencakup tersedianya penampilan fasilitas fisik, peralatan, sumberdaya manusia, materi-materi untuk komunikasi yang merupakan bukti nyata (Tangible) pelayanan.

Pada penilaian standar kualitas layanan perguruan tinggi berdasarkan Akreditasi Insitusi Perguruan Tinggi (AIPT) yang disyaratkan oleh Badan Akreditasi Nasional Perguruan Tinggi (BAN - PT), harus memenuhi 7 standar, meliputi : (1) Visi, misi, tujuan dan sasaran, serta strategi pencapaian, (2) Tata pamong, kepemimpinan, sistem pengelolaan, dan penjaminan mutu, (3) Mahasiswa dan lulusan, (4) Sumber daya manusia, (5) Kurikulum, pembelajaran dan suasana akademik, (6) Pembiayaan, sarana dan prasarana, serta sistem informasi, (7) Penelitian, pelayanan/pengabdian kepada masyarakat dan kerjasama. Dalam penilaian kinerja pelayanan publik menteri pendayagunaan aparatu negara nomor : Kep/25/M.PAN/2/2004 tengan indek kepuasan masyarakat menhagharuskan bahwa pelayanan minimal harus memenuhi 14 aspek pelayanan yang meliputi : Prosedur Pelayanan, Persyaratan Pelayanan, Kejelasan petugas pelayanan, Kedisiplinan petugas pelayanan, Tanggung jawab petugas pelayanan, Kemampuan petugas pelayanan, Kecepatan pelayanan, Keadilan mendapatkan pelayanan, Kesopanan dan keramahan petugas, Kewajaran biaya pelayanan, Kepastian biaya pelayanan, Kepastian jadwal pelayanan, Kenyamanan lingkungan, Kenyamanan pelayanan.

\section{Metode Penelitian}

Penelitian ini merupakan penelitian studi literatur dan studi kasus yang mengambil tempat penelitian di beberapa Universitas negeri dan swasta di Kota Bandung. Penelitian ini menggabungkan, pendekatan teori/konsep,penelitian dan pengukuran kualitas layanan akademik perguruan tinggi, evaluasi model penelitian penelitian manajemen kualitas layanan terdahulu di perguruan tinggi, evaluasi standar kualitas layanan perguruan tinggi berdasarkan Akreditasi Institusi Perguruan Tinggi 
(AIPT) Badan Akreditasi Nasional Perguruan Tinggi (BAN- PT), evaluasi penilaian kinerja pelayanan publik Tentang Indeks Kepuasan Masyarakat. Pengumpulan data dilakukan dengan cara studi dokumen atau data sekunder dan pengumpulan data primer yaitu dengan melakukan penyebaran kuesioner pengukuran kualitas layanan untuk karyawan. Analisis data dalam penelitian ini adalah Structural Equation Modeling (SEM). Menurut Sugiyono (2010:323), di dalam analisis SEM dapat dilakukan tiga macam kegiatan secara serentak, yaitu pengecekan validitas dan reliabilitas instrumen (berkaitan dengan analisis faktor konfirmatori), pengujian model hubungan antar variabel (berkaitan dengan analisis jalur), dan kegiatan untuk mendapatkan suatu model yang cocok untuk prediksi (berkaitan dengan analisis regresi atau analisis model struktural).

\section{Hasil Penelitian dan Pembahasan}

Berdasarakan perhitungan melalui analisis data SEM diperoleh Nilai Validitas (loading factor) dan Reliabilitas (consruct reliability) seperti terlihat pada tabel 2.

Tabel 2. Nilai Validitas (loading factor) dan Reliabilitas (consruct reliability)

\begin{tabular}{|c|c|c|c|c|c|c|}
\hline Indikator & $\begin{array}{l}\text { Faktor } \\
\text { Loading } \\
\text { (standar } \\
\text { ied) }\end{array}$ & $\begin{array}{l}\text { Hasil } \\
\text { t- } \\
\text { value }\end{array}$ & $\mathbf{R}^{2}$ & $\begin{array}{l}\text { Erro } \\
\text { rvar }\end{array}$ & $\mathbf{C R}$ & $\begin{array}{c}\text { Keteran } \\
\text { gan }\end{array}$ \\
\hline $\begin{array}{l}\text { Penampilan fisik gedung perkuliahan dan kampus } \\
\text { secara keseluruhan (TA1) }\end{array}$ & 0,60 & 11,49 & 0,59 & 0,55 & \multirow{9}{*}{0,80} & $\mathrm{~V}$ and $\mathrm{R}$ \\
\hline $\begin{array}{l}\text { Kondisi tempat sholat di lingkungan kampus } \\
\text { (penataan,fasilitas, kebersihan) (TA2) }\end{array}$ & 0,52 & 11,40 & 0,52 & 0,28 & & $\mathrm{~V}$ and $\mathrm{R}$ \\
\hline $\begin{array}{l}\text { Kondisi ruang tunggu dosen di gedung perkuliahan } \\
\text { (penataan, fasilitas, kebersihan) (TA3) }\end{array}$ & 0,68 & 13,05 & 0,67 & 0,50 & & $\mathrm{~V}$ and $\mathrm{R}$ \\
\hline Kondisi ruang kuliah yang memadai (TA4) & 0,70 & 12,99 & 0,69 & 0,22 & & $\mathrm{~V}$ and $\mathrm{R}$ \\
\hline $\begin{array}{l}\text { Kondisi toilet di gedung perkuliahan dan lingkungan } \\
\text { kampus (penataan, fasilitas, kebersihan) (TA5) }\end{array}$ & 0,76 & 13,97 & 0,75 & 0,27 & & $\mathrm{~V}$ and $\mathrm{R}$ \\
\hline $\begin{array}{c}\text { Kondisi ruang kerja dosen (penataan, fasilitas, } \\
\text { kebersihan) TA6 }\end{array}$ & 0,66 & 11,66 & 0,66 & 0,15 & & $\mathrm{~V}$ and $\mathrm{R}$ \\
\hline Fasilitas Tempat parkir dosen yang memadai (TA7) & 0,59 & 12,82 & 0,60 & 0,35 & & $\mathrm{~V}$ and $\mathrm{R}$ \\
\hline $\begin{array}{l}\text { Kondisi fasilitas kerja di ruang kerja dosen dan ruang } \\
\text { administrasi (TA8) }\end{array}$ & 0,72 & 12,21 & 0,73 & 0,27 & & $\mathrm{~V}$ and $\mathrm{R}$ \\
\hline $\begin{array}{l}\text { Fasilitas mengajar dan alat bantu (komputer, inFocus, } \\
\text { papan tulis, dll) yang digunakan di ruang kuliah (TA9) }\end{array}$ & 0,65 & $* *$ & 0,64 & 0,31 & & $\mathrm{~V}$ and $\mathrm{R}$ \\
\hline $\begin{array}{c}\text { Layanan administratif yang diberikan kepada dosen } \\
\text { meliputi kedisiplinan, tanggung jawab, kemampuan } \\
\text { dan kecepatan (EMP1) }\end{array}$ & 0,73 & 19,15 & 0,72 & 0,22 & \multirow[b]{5}{*}{0,94} & $\mathrm{~V}$ and $\mathrm{R}$ \\
\hline $\begin{array}{l}\text { Perhatian Pengelola PT terhadap pemenuhan kebutuhan } \\
\text { Dosen (EMP2) }\end{array}$ & 0,66 & 19,40 & 0,68 & 0,24 & & $\mathrm{~V}$ and $\mathrm{R}$ \\
\hline $\begin{array}{c}\text { Layanan dalam proses peningkatan jabatan fungsional } \\
\text { Dosen meliputi kedisiplinan, tanggung jawab, } \\
\text { kemampuan dan kecepatan (EMP3) }\end{array}$ & 0,69 & 17,82 & 0,65 & 0,23 & & $\mathrm{~V}$ and $\mathrm{R}$ \\
\hline $\begin{array}{c}\text { Layanan dalam proses peningkatan pendidikan Dosen } \\
\text { meliputi kedisiplinan, tanggung jawab, kemampuan } \\
\text { dan kecepatan (EMP4) }\end{array}$ & 0,65 & 16,88 & 0,64 & 0,28 & & $\mathrm{~V}$ and $\mathrm{R}$ \\
\hline $\begin{array}{l}\text { Program peningkatan kompetensi dosen yang jelas } \\
\text { untuk setiap dosen (pelatihan, seminar, workshop)( } \\
\text { EMP5) }\end{array}$ & 0,63 & 17,35 & 0,63 & 0,31 & & $\mathrm{~V}$ and $\mathrm{R}$ \\
\hline
\end{tabular}




\begin{tabular}{|c|c|c|c|c|c|c|}
\hline Indikator & $\begin{array}{c}\text { Faktor } \\
\text { Loading } \\
\text { (standar } \\
\text { ied) }\end{array}$ & $\begin{array}{l}\text { Hasil } \\
\text { t- } \\
\text { value }\end{array}$ & $\mathbf{R}^{2}$ & $\begin{array}{l}\text { Erro } \\
\text { rvar }\end{array}$ & CR & $\begin{array}{l}\text { Keteran } \\
\text { gan }\end{array}$ \\
\hline $\begin{array}{c}\text { Kemudahan melakukan komunikasi dengan pimpinan } \\
\text { Perguruan Tinggi /Universitas (EMP6) }\end{array}$ & 0,61 & 20,38 & 0,61 & 0,27 & & $\mathrm{~V}$ and $\mathrm{R}$ \\
\hline $\begin{array}{c}\text { Kemudahan mendapatkan informasi berkaitan dengan } \\
\text { pelaksanaan tugas mengajar secara cepat dan benar } \\
\text { (jadwal, ruangan) (EMP7) }\end{array}$ & 0,83 & $* *$ & 0,83 & 0,28 & & $\mathrm{~V}$ and $\mathrm{R}$ \\
\hline $\begin{array}{c}\text { Kualitas layanan Universitas menyangkut transparansi, } \\
\text { akuntabilitas, responsibilitas, kemandirian dan } \\
\text { keadilan.( RES1) }\end{array}$ & 0,68 & 15,66 & 0,69 & 0,31 & \multirow{8}{*}{0,85} & $\mathrm{~V}$ and $\mathrm{R}$ \\
\hline $\begin{array}{c}\text { Layanan tata laksana sesuai dengan kebutuhan (pada } \\
\text { pelaksanaan PBM) (RES2) }\end{array}$ & 0,74 & 15,54 & 0,73 & 0,43 & & $\mathrm{~V}$ and $\mathrm{R}$ \\
\hline $\begin{array}{c}\text { Layanan Satpam sesuai dengan kebutuhan (keamanan, } \\
\text { kenyamanan) (RES3) }\end{array}$ & 0,79 & 15,71 & 0,77 & 0,26 & & $\mathrm{~V}$ and $\mathrm{R}$ \\
\hline $\begin{array}{l}\text { Komunikasi antara dosen dengan pihak Jurusan/prodi } \\
\text { (RES4) }\end{array}$ & 0,75 & 15,02 & 0,75 & 0,32 & & $\mathrm{~V}$ and $\mathrm{R}$ \\
\hline $\begin{array}{c}\text { Komunikasi antara dosen dengan unit-unit di tingkat } \\
\text { universitas (RES5) }\end{array}$ & 0,68 & 17,05 & 0,67 & 0,26 & & $\mathrm{~V}$ and $\mathrm{R}$ \\
\hline $\begin{array}{c}\text { Dukungan atasan terhadap dosen dalam memberikan } \\
\text { layanan kepada mahasiswa (RES6) }\end{array}$ & 0,77 & 16,59 & 0,77 & 0,32 & & $\mathrm{~V}$ and $\mathrm{R}$ \\
\hline Komunikasi antar dosen (RES7) & 0,76 & 15,83 & 0,75 & 0,16 & & $\mathrm{~V}$ and $\mathrm{R}$ \\
\hline $\begin{array}{c}\text { Fasilitas untuk menyampaikan ide,masukan, dan } \\
\text { komplain kepada pihak pengelola Perguruan Tinggi / } \\
\text { Universitas (suasana akademik) (RES8) }\end{array}$ & 0,69 & 18,95 & 0,69 & 0,19 & & $\mathrm{~V}$ and $\mathrm{R}$ \\
\hline $\begin{array}{l}\text { Kejelasan prosedur kerja yang berkaitan dengan dosen } \\
\text { (akademik, PBM, kenaikan jabatan,dll) (REL1) }\end{array}$ & 0,72 & 19,38 & 0,70 & 0,22 & \multirow{7}{*}{0,97} & $\mathrm{~V}$ and $\mathrm{R}$ \\
\hline $\begin{array}{c}\text { Penerapan peraturan yang telah ada secara benar dan } \\
\text { menyeluruh (REL2) }\end{array}$ & 0,69 & 19,89 & 0,69 & 0,19 & & $\mathrm{~V}$ and $\mathrm{R}$ \\
\hline Sosialisasi Kebijakan dilakukan dengan tepat (REL3) & 0,73 & 19,57 & 0,67 & 0,20 & & $\mathrm{~V}$ and $\mathrm{R}$ \\
\hline $\begin{array}{c}\text { Program kerja pimpinan universitas yang jelas dalam } \\
\text { upaya pencapaian visi dan misi (REL4) }\end{array}$ & 0,67 & 18,30 & 0,67 & 0,20 & & $\mathrm{~V}$ and $\mathrm{R}$ \\
\hline Kejelasan dalam penilaian kinerja dosen (REL5) & 0,71 & 16,07 & 0,70 & 0,15 & & $\mathrm{~V}$ and $\mathrm{R}$ \\
\hline $\begin{array}{c}\text { Persamaan visi dan misi antar bagian di lingkungan } \\
\text { universitas dalam hal pemberian pelayanan kepada } \\
\text { mahasiswa (REL6) }\end{array}$ & 0,64 & $* *$ & 0,63 & 0,19 & & $\mathrm{~V}$ and $\mathrm{R}$ \\
\hline $\begin{array}{l}\text { Dukungan sistem informasi yang memadai, akurat, dan } \\
\text { terintegrasi (jaringan internet, IT, dll) (REL7) }\end{array}$ & 0,56 & $* *$ & 0,54 & 0,20 & & $\mathrm{~V}$ and $\mathrm{R}$ \\
\hline $\begin{array}{l}\text { Ketersediaan buku-buku penunjang untuk mengajar } \\
\text { yang memadai (buku ajar, text book, jurnal ) (ASR1) }\end{array}$ & 0,68 & 20,97 & 0,69 & 0,25 & \multirow{6}{*}{0,95} & $\mathrm{~V}$ and $\mathrm{R}$ \\
\hline $\begin{array}{c}\text { Keamanan dan kenyamanan di lingkungan kampus } \\
\text { (pada saat kegiatan PBM dan kegiatan administrasi) } \\
\text { (ASR2) }\end{array}$ & 0,69 & 12,01 & 0,67 & 0,18 & & $\mathrm{~V}$ and $\mathrm{R}$ \\
\hline $\begin{array}{c}\text { Adanya jaminan kesehatan bagi dosen (kejelasan } \\
\text { aturan dan informasi, pelaksanaan pemberian jaminan } \\
\text { kesehatan) (ASR3) }\end{array}$ & 0,63 & 16,15 & 0,64 & 0,80 & & $\mathrm{~V}$ and $\mathrm{R}$ \\
\hline $\begin{array}{c}\text { Ketersediaan layanan untuk publikasi karya ilmiah } \\
\text { dosen (ASR4) }\end{array}$ & 0,55 & 18,83 & 0,56 & 0,28 & & $\mathrm{~V}$ and $\mathrm{R}$ \\
\hline $\begin{array}{l}\text { Fasilitas dan dana bagi dosen untuk melakukan } \\
\text { penelitian dan pengabdian masyarakat (ASR5) }\end{array}$ & 0,58 & 15,81 & 0,60 & 0,20 & & $\mathrm{~V}$ and $\mathrm{R}$ \\
\hline $\begin{array}{c}\text { Program Jaminan Hari Tua (pensiun) yang jelas dan } \\
\text { memadai (ASR6) }\end{array}$ & 0,54 & 18,83 & 0,54 & 0,29 & & $\mathrm{~V}$ and $\mathrm{R}$ \\
\hline
\end{tabular}




\begin{tabular}{|c|c|c|c|c|c|c|}
\hline Indikator & $\begin{array}{l}\text { Faktor } \\
\text { Loading } \\
\text { (standar } \\
\text { ied) }\end{array}$ & $\begin{array}{c}\text { Hasil } \\
t- \\
\text { value }\end{array}$ & $\mathbf{R}^{2}$ & $\begin{array}{l}\text { Erro } \\
\text { rvar }\end{array}$ & $\mathbf{C R}$ & $\begin{array}{l}\text { Keteran } \\
\text { gan }\end{array}$ \\
\hline $\begin{array}{c}\text { Program kesejahteraan dosen yang sesuai dengan } \\
\text { kebutuhan (ASR7) }\end{array}$ & 0,63 & $* *$ & 0,64 & 0,26 & & $\mathrm{~V}$ and $\mathrm{R}$ \\
\hline $\begin{array}{l}\text { Sistem pengelolaan universitas mencakup perencanaan, } \\
\text { pengorganisasian, staffing, leading dan pengawasan } \\
\text { (TKL1) }\end{array}$ & 0,70 & 18,01 & 0,83 & 0,20 & & $\mathrm{~V}$ and $\mathrm{R}$ \\
\hline $\begin{array}{c}\text { Sistem pengelolaan sumber daya manusia yang lengkap } \\
\text { dari perencanaan, rekruitmen, pengembangan karir, } \\
\text { penghargaan dan sanksi (TKL2) }\end{array}$ & 0,63 & 17,61 & 0,50 & 0,24 & & $\mathrm{~V}$ and $\mathrm{R}$ \\
\hline Program pengukuran kepuasan dosen (TKL3) & 0,58 & 19,80 & 0,45 & 0,22 & & $\mathrm{~V}$ and $\mathrm{R}$ \\
\hline $\begin{array}{c}\text { Sistem pengelolaan dana yang mencakup perencanaan } \\
\text { penerimaan, pengalokasian, pelaporan audit, } \\
\text { monitoring dan evaluasi. (TKL4) }\end{array}$ & 0.63 & $* *$ & 0,50 & 0,17 & 0,92 & $\mathrm{~V}$ and $\mathrm{R}$ \\
\hline
\end{tabular}

TA = Tangible (Tampilan Elemen Fisik), EMP = Emphaty (Empati), RES = Responsiveness (Daya Tanggap), REL = Reliability (Kehandalan), ASR = Asurance (Jaminan), TKL = Tatakelola/pengelolaan

Berdasarkan Tabel 2 untuk pengujian validitas ternyata loading factor dari semua indikator tidak ada yang lebih kecil dari 0,50. Dengan demikian, maka semua indikator dinyatakan valid dan proses evaluasi model dapat dilanjutkan, untuk pengujian reliabilitas, sebagaimana ditunjukan pada Tabel 2. tidak ada nilai construct reliability (CR) yang nilainya di bawah 0.70 maka semua konstruk dalam penelitian ini layak untuk digunakan dalam model.

Tabel 3. Hasil Perhitungan Indeks Goodness of fit

\begin{tabular}{|l|c|c|c|}
\hline \multicolumn{1}{|c|}{ Kriteria } & Hasil Model & Nilai Kritis & Kesimpulan \\
\hline Chi-Square & 9580 & Kecil & Fit \\
\hline RMSEA & 0,014 & $\leq 0,08$ & Fit \\
\hline GFI & 0,88 & $\geq 0,90$ & Marginal Fit \\
\hline AGFI & 0,86 & $\geq 0,90$ & Marginal Fit \\
\hline CFI & 0,96 & $\geq 0,95$ & Fit \\
\hline NNFI & 0,90 & $\geq 0,90$ & Fit \\
\hline NFI & 0,90 & $\geq 0,90$ & Fit \\
\hline
\end{tabular}

Sumber : Diolah dari data penelitian

Berdasarkan Tabel 3. dapat dilihat bahwa semua kriteria pengujian menunjukkan hasil yang baik. Pengujian model yang dilakukan menghasilkan konfirmasi yang baik atas dimensi - dimensi faktor dan hubungan kausalitas antar faktor. Dengan demikian model tersebut dapat diterima.

Adapun model usulan kualitas layanan akademik perguruan tinggi untuk dosen seperti pada gambar 1 . 


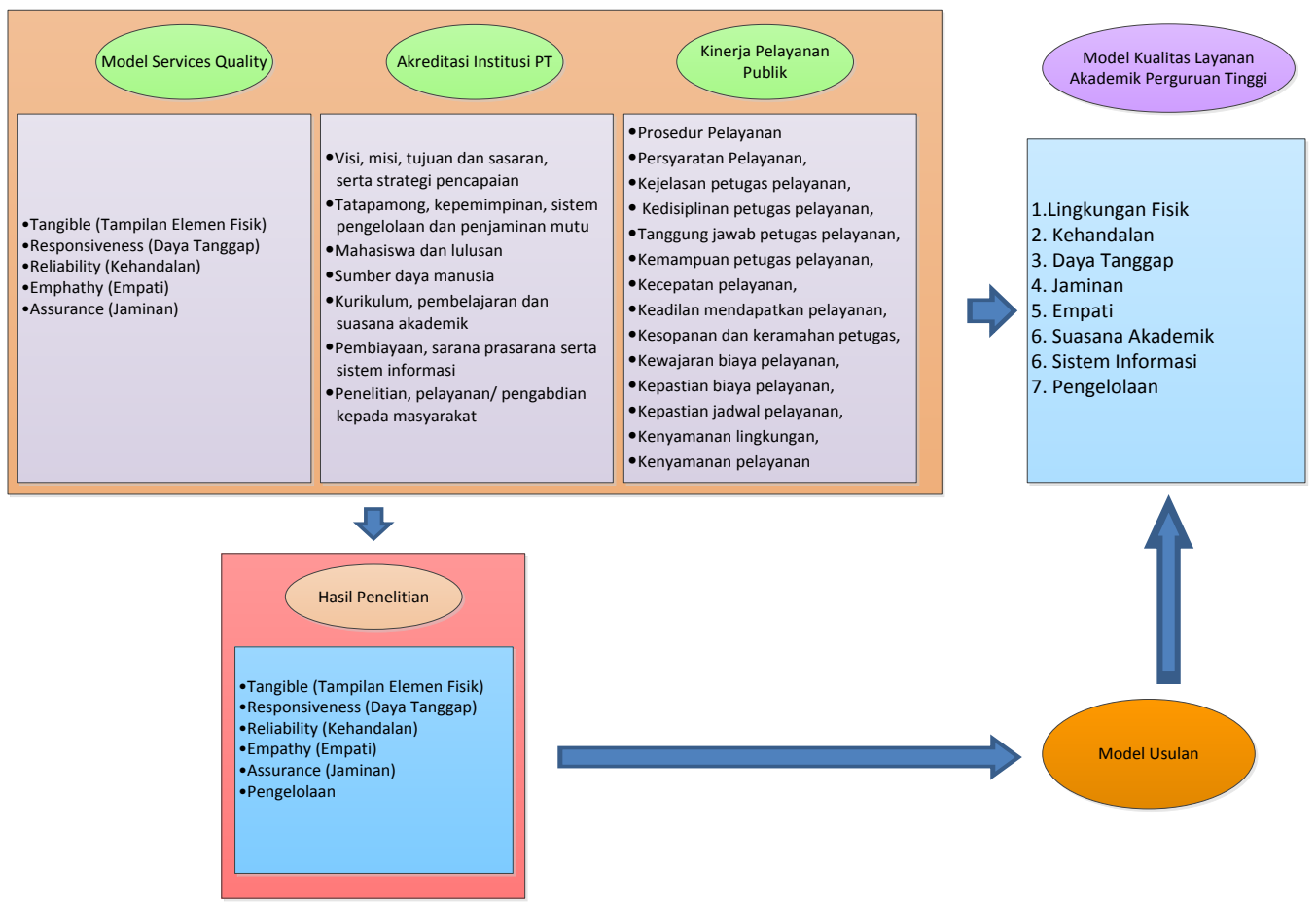

Gambar 1. Model Usulan Kualitas Layanan Akademik Perguruan Tinggi

\section{Kesimpulan}

Berdasarkan rumusan masalah, hasil penelitian, dan pembahasan yang disajikan sebelumnya dapat ditarik kesimpulan,. Berdasarkan perhitungan Indeks Goodness of fit bahwa semua kriteria pengujian menunjukkan hasil yang baik. Pengujian model yang dilakukan menghasilkan konfirmasi yang baik atas dimensi - dimensi faktor dan hubungan kausalitas antar faktor. Dengan demikian model tersebut dapat diterima. Berdasarkan hasil penelitian faktor - faktor pembentukan kualitas layanan akademik internal adalah tampilan elemen fisik, empati, daya tanggap, kehandalan, jaminan serta pengelolaan. Sedangkan model yang diusulkan kualitas layanan akademik perguruan Tinggi adalah lingkungan fisik, kehandalan dalam layanan, daya tanggap, jaminan, empati, suasana akademik, sistem informasi serta pengelolaan.

\section{Ucapan Terima Kasih}

Penulis mengucapkan terima kasih kepada Direktorat Jenderal Pendidikan Tinggi (DIRJEN DIKTI) Direktorat Penelitian dan Pengabdian kepada Masyarakat (DP2M) Departemen Pendidikan dan Kebudayaan (DEPDIKBUD) yang telah membiayai penelitian ini dan LPPM Universitas Islam Bandung atas terlaksananya acara Seminar Nasional Penelitian dan Pengabdian 2015 ini dan kepada pihak Panitia Prosiding atas kerjasamanya untuk memuat makalah seminar terpilih. 


\section{Daftar pustaka}

Kotler, Philips, and Keller, Kevin Lane., (2009). Marketing Management ,Pearson, Prentice Hall.

Kusnendi. (2005). Konsep dan Aplikasi Model Persamaan Struktural (SEM) dengan Program LISREL 8, Bandung : Jurusan Pendidikan Ekonomi FPIPS.

Kusnendi. (2008). Model - Model Persamaan Struktural, satu dan Multigroup sampel dengan LISREL, Penerbit Alfabeta, Bandung.

http : /www.ban-pt depdiknas.go.id

http://pdpt.dikti.go.id/26 Juni 2015

Nugraha, (2011) Management of Quality Services in Higher Education. International Seminar on Improving the Quality of Student Achievement in Higher Education, Bangkok, Thailand.

Nugraha, (2011) Penerapan Dimensi Kualitas Pelayanan Dalam Mengukur Kepuasan Mahasiswa di Perguruan Tinggi, Karya Ilmiah.Dipresentasikan dalam Seminar Nasional Industrial Services 2011 di Universitas Sultan Ageng Tirtayasa.

Nugraha, dan Reni (2012) Analisis Pengukuran Kepuasan Mahasiswa terhadap Kualitas Layanan Akademik Perguruan Tinggi Melalui Aplikasi Model Student Satisfaction Inventory (SSI) (Studi Kasus di Universitas Islam Bandung), Karya Ilmiah. Dipresentasikan dalam Seminar Nasional SnaPP 2012 di LPPM Universitas Islam Bandung.

Nugraha, Reni dan Aswardi (2014) Pengembangan Model Student Satisfaction Inventory (SSI) Untuk Peningkatan Kualitas Layanan Akademik di Perguruan Tinggi, Karya Ilmiah. Dipresentasikan dalam Seminar Nasional SnaPP 2014 di LPPM Universitas Islam Bandung.

Parasuraman, A., V.A. Zeithaml and L.L Berry (1985) "A Conceptual Model of Service Quality and Its Implication for Future Research”, Journal of Marketing, Vol 49, Fall, pp. 41-50.

Peraturan Pemerintah Republik Indonesia Nomor 66 Tahun 2010 Tentang Perubahan atas Peraturan Pemerintah Nomor 17 Tahun 2010 tentang Pengelolaan dan Penyelenggaraan Pendidikan.

Peraturan menteri Pendayagunaan Aparatur Negara (Menpan) nomor : KEP/25/M.PAN/2/2004 Tentang Indeks Kepuasan Masyarakat

Sallis, Edward. (1993). Total Quality Management in Education. New Jersey. Prentice Hall.Inc. Engliwood Cliffs.

Sallis, Edward. (2011). Manajemen Mutu Terpadu Pendidikan. Penerbit IRCiSoD. Yogyakarta.

Sugiyono, (1999) Statistika Untuk Penelitian, Penerbit, CV Alfabeta, Bandung,.

Tjiptono, Fandy.,dan Chandra, Gregorious, (2005) Services, Quality dan Satisfaction, Penerbit Andi, Yogyakarta.

Zeithaml, Valarie A., A. Pasuraman and Leonard L. Berry, (1990) Delivering Quality Service : Balancing Customer Perception and Expectation, A Division of Macmillan Inc, New York.

Zeithaml, Valarie A., Bitner, Mary Jo., and Gremler, Dwayne D,, (2008) Service Marketing : Integrated Customer Focus Across the Firm, McGraw - Hill Education (UK) Limited.

Zeshan, et al (2010) Assessing Service Quality In Business Schools: Implications For Improvement. $3^{\text {rd }}$ International Conference on Assesing Quality in Higher Education, Lahore - Pakistan. 